\title{
THE ROLE OF THE MOSQUE IN ECONOMIC EMPOWERMENT AND COMMUNITY WELFARE THROUGH MSMES IN THE SOUTH JAKARTA REGION
}

\author{
Imam Sofii; Indah Pertiwi \\ Universitas Pamulang \\ e-mail:imam_mpd@yahoo.co.id; ind4h.pertiwi@gmail.com
}

\begin{abstract}
The purpose of this research is to map the various basic concepts of community empowerment to function mosques, actualize and develop socioeconomic values. This research uses a qualitative research approach of participatory action research. namely interacting and socializing, so that it will improve capacity building and self-confidence from society. The research sites are Pondok Indah Grand Mosque and Jami' Assakinah Mosque. The results of this study indicate that the role of the mosque in realizing the welfare of the community through UMKM is an actualization that is able to guarantee the economic independence of the community. It also helps the economic empowerment of the surrounding community, at the same time. The indicators found in these two mosques are the presences of professional and qualified personnel. They have the adequate infrastructure and strategic location surrounded by elite housing and offices. The mosque is easy to reach. Furthermore, it is close to objects that become empowerment, such as markets and street vendors. The economic empowerment of the mosque-based community was initiated by BMT, in order to optimize the function and role of the mosque as the center of civilization for the people and the economic welfare of the congregation or the community around the mosque. Besides that, it is also a strategy in order to empower the economy of the people by creating a Mosque Micro loan program (PMM). This program is designed for micro entrepreneurs who have difficulty obtaining or accessing capital.
\end{abstract}

Keywords: mosque; economic empowerment; community welfare; UMKM

\section{Introduction}

A mosque is a place that has the value of goodness and benefit for the people, both in worldly dimensions and eschatological matters. In fact, based on reality in society, the function of a mosque with a worldly dimensions does not have a maximum role in the development of the ummah and Islamic civilization. Whereas a mosque for Muslims is a strategic socio-religious (religious and social) institution. Mosques, ideally, should be built or established not only to realize faith and piety but also to prosper various aspects of people's life.

Mosques are not only limited to centers of worship activities for their congregations, but they are also expected to become centers of social and economic activities for their congregations. The development of community economic resources in building mosques and empowering congregations is a big ideal about the revitalization of the function of mosques as a forum for community empowerment. This great ideal is something that is very historical, indeed. In accordance with the context of Islam, ideally, the mosque is the main and most 
important pillar for the formation of an Islamic society. Because the Muslim community will not be formed firmly and neatly unless there is a commitment to the Islamic system, creed and order. This cannot be raised except in mosques.

The concept of empowerment is important because it can provide a positive perspective on the use of existing mosque resources. An empowered community is not seen as a passive object of service recipients, but rather a community that has various potentials and abilities that can be empowered. Islamic community empowerment activities can be carried out through assistance by providing motivation, raising awareness, fostering aspects of knowledge and attitudes to increase capacity, mobilize productive resources and develop networks. ${ }^{1}$

These economic problems often have a negative impact on social life such as social disparities, poverty, malnutrition, unemployment and low education. Therefore, to overcome these problems, it is necessary to have an innovation to create jobs ranging from entrepreneurship training, talent interest networking, women empowerment, motivational seminars to open micro, small and medium enterprises for people who have a strong enthusiasm and spirit. They also already have the ability and tenacity in opening a business to be pioneered. This is one way to optimize the potential of the community

One of the forms of congregational/community business development is the provision of capital and the development of human resource, infrastructure, production, and marketing. Jama'ah business development in the economic sector, especially in the field of small and medium enterprises, is felt to succeed in making the prosperous congregation. The problem of limited capital will be one of the contributions of the mosque management. Therefore, a mosque is a religious institution that is inseparable from the spiritual, social and cultural life of Muslims. Wherever Muslims are, there must be a mosque. Islam places mosques in a strategic position. In general, mosques have many functions, including the social, educational and community unifying fields. ${ }^{2}$

Understanding the mosque universally means to comprehend it as a social instrument of Islamic society that cannot be separated from the Islamic community itself. The existence of mosques in general is a manifestation of the aspirations of Muslims as places of worship that occupy a central function. Related to its strategic function, it is necessary to develop, as well as possible, both in terms of physical buildings and prosperity activities. In terms of quantity of more than 700 thousand mosques throughout Indonesia, coupled with mushalla and mosques in shops, the social, cultural, political, economic, health and educational qualities of Muslims can be really effectively empowered. In fact, the authentic values of mosques are not entirely absorbed, since Muslims tend to prioritize ceremonial rituals and underestimate the social functions of mosques.

Mosques cannot provide optimal answers to the scientific and Islamic problems of the people. Aside from the month of Ramadan, mosques are increasingly quiet from socioreligious activities because they are used more for prayer, recitation, dhikr and reading the al-

\footnotetext{
${ }^{1}$ Achmad Chaidir, Strategi Peningkatan Peran Lembaga Kemasyarakatan dalam Penanggulangan Kemiskinan di Kota Pekanbaru (Riau: Universitas Riau, 2009), 13.

2 Dedi Susanto, "Penguatan Manajemen Masjid Darussalam di Wilayah RW 1V Kelurahan Banjardowo Kecamatan Genuk Kota Semarang” (Skripsi--Universitas Semarang, 2014), 34.
} 
Quran. Mosques are not able to eradicate congregational corruption and tackle drugs that afflict teenagers. One of the reasons is that the mosque management is not creative and responsive to various problems of the ummah. It does not follow and master scientific developments and technological advances. ${ }^{3}$

The egalitarian characteristics of society do not make this mosque as role models such as the existence of mosques and Islamic boarding schools in Java. According to the admission of one of the administrators, the mosque did not produce a cleric figure, but created an ulama. It's just that the attraction of this mosque raises well-known and qualified scholars. The $d a$ 'wah activities of this mosque communicate effectively and have weighty $d a$ 'wah materials.

In general, preachers and others are able to mobilize and influence the masses by using beautiful, interesting and rhetorical language, but in reality, they institutionally have been able to carry out socio-religious transformations for the community, so that this mosque has become a people's reference. For instance, Islam in various regions of Indonesia such as DKI Jakarta, especially among the ummah in general. This means that there has been a change in the perception and image of the Muslim community and its surroundings, which were originally focused on the popularity of the previously established Islamic bases. The mosque prefers to play the role of inviting intellectual people to others to do amar ma'ruf nahi munkar.

The various programs designed and implemented aim to change or reform a community or society from a state of helplessness to being empowered by focusing on fostering community potential and independence. One of the principles in empowerment is the mastery of socio-economic capacity, namely, how the weak community can gain access to information, knowledge and skills, participation in social organizations, and financial resources. They also can enhance the ability to utilize and manage production, distribution and service mechanisms.

Capability in this context concerns individual performance which is a form of individual competence that can be increased through the learning process or directly involved in the field. During the time of the Prophet Muhammad's Apostolate, the social problems at that time were significant because of many of the Prophet's companions needed social assistance as a risk of their faith and as a consequence of their struggles. Besides that, other social problems such as poverty has always existed throughout the ages. ${ }^{4}$

To overcome this social problem, Rasulullah and his companions made the mosque a place for social activities, for example by collecting zakat, infaq and sadaqah through the mosque and then distributing it to friends who needed it. Therefore, the existence of mosques had a very large function during the time of the Prophet and it was felt well by the community at large so that people became in love with mosque.

From the arisen problems, it becomes an interesting thing to analyse. Among other things, the problem of the economic downturn of the community around the mosque in the

\footnotetext{
${ }^{3}$ Dalmeri, "Revitalisasi Fungsi Masjid Sebagai Pusat Ekonomi dan Dakwah", Jurnal Walisongo, Volume 22, Nomor 2 (2014), 147.

4 Yustina Chrismardani, "Komunikasi Pemasaran Terpadu: Implementasi untuk UMKM", Jurnal Neo-bis, Volume 8, Nomor 2, (2014), 176-189.
} 
South Jakarta area will be the focus of this research. This is one of the unique phenomena to be studied with da'wah bi al-hal activities based on the development of Micro, Small and Medium Enterprises (UMKM) as a booster for community welfare and the activeness of the congregation in participating in programs organized by the mosque. ${ }^{5}$

Seeing the phenomenon that is developing among the ummah, a new paradigm is needed in seeing the economic empowerment of this people. They must be positioned as subjects in empowerment because they are the inclusive and central part of microeconomic development. It is necessary to develop partnerships between the community, the community and the government, the private sector and non-governmental organizations which are the largest social capital in society building. ${ }^{6}$

The description of the climatic conditions of the jama'ah UMKM in the mosque in the South Jakarta area at this time, seen from the opportunity for empowerment from time to time, place to place, and from sector to sector, has not indicated the amount of material welfare of the congregation. It requires training, capital financing, development in terms of infrastructure, human resources, production, marketing, providing motivation, supervision and assistance to congregations that are targeted and have been recorded in the map of the mosque da'wah in the South Jakarta area.

\section{Literature Review}

The research position to be examined by researchers is a development of the results of previous research. This is to avoid the same findings. As far as the researchers' observations, there are no detailed observations that discuss the Role of Mosques in Economic Empowerment and Community Welfare through Micro, Small and Medium Enterprises (UMKM). Even though there are works that have discussed the development strategy of the mosque congregation, researcher focused more on the role of mosques in economic empowerment through micro, small and medium enterprises (UMKM) in the congregation to promote the economic welfare of the community around the mosque in the South Jakarta area.

Mosque comes from the Arabic language sajada-yasjudu-sujud, which means obedient, and bow with respect (ta'zim). Mosques are an integral part of the spiritual, social and cultural life of Muslims. According to the language of the mosque is isim makan (noun for the meaning of place) the origin of the word from fi'il madi "sajada" which means showing the place of prostration. ${ }^{7}$

In the Koran, the meaning of prostration is explained. First, prostration (Q.S. al-Baqarah 34) means respect and recognition of the superiority of others. Like the prostration of an angel to the prophet Adam. Second, prostration (Q.S. Thaha 70) means awareness (inshaff) of the mistakes and the recognition of other parties. Like the prostration of the pharaoh sorcerers. Third, prostration (Q.S. al-Rahman 6) means following or conforming to Allah's decrees relating to His destinies that apply to the universe, such as the prostration of the Stars and trees.

\footnotetext{
5 Suparman Mannuhung, dkk, "Manajemen Pengelolaan Masjid dan Remaja Masjid di Kota Palopo", Jurnal Pengabdian Masyarakat, Volume 1, Nomor 1 (2018), 14-21.

${ }^{6}$ Mardikanto, Konsep Pemberdayaan Masyarakat (Surakarta: Tiga Serangkai, 2010), 86.

${ }^{7}$ E. Suherman, Manejemen Masjid Kiat Sukses Meningkatkan Kualitas SDM Melalui Optimalisasi Kegiatan Umat Berbasis Pendidikan Berkualitas Unggul (Bandung: Alfabeta, 2012), 62.
} 
In terminology, a mosque is a building or an environment that has clear boundaries (fence). The word mosque is mentioned in the Koran 28 times, 22 times of it in the singular form, and 6 times in the plural, 15 times of which talk about the Grand Mosque. The time of the Prophet at the Quba mosque, apart from worship, it also functions as a place for education and teaching the Quran. It is the same in the time of friends, who made the mosque a reflection of love for Allah, and evidence of the level of cultural development. In Indonesia, from cities to remote villages, a mosque has the potential to advance the ummah and nation. Not only as a means of worship in fostering the ummah, but also for various social, economic, and educational aspects. According to news republika.co.id, from DMII data, the total number of mosques and prayer rooms in Indonesia is more than 800 thousand. The potential quantity of mosques and prayer rooms needs to be managed to bridge the various needs of the ummah. $^{8}$

According to Nurseri and Wijaya, the function of mosques for the happiness of the world and the hereafter requires professional managements. First, physical management of mosques including stewardship, construction and physical maintenance of mosques, maintenance of cleanliness and elegance of mosques, management of parks and facilities. Second, functional management, the development of mosque functions is the utilization of the role of the mosque as a center of worship, education, social, economic, political, cultural, preaching and Islamic civilization. ${ }^{9}$ According to Ari Saputra et al in their research, mosques have succeeded in improving the welfare of the community, which included traders, carrying laborers, pedicab pedals and providing scholarships for underprivileged children. The revitalization of mosques is also carried out by strengthening the capacity of ta'mir as the spearhead of community service covering the fields of idärah, imarah and ri'ayah. Ta'mir as a form of Islamic $d a$ 'wah organization. Its existence is to prosper the mosque, especially in managing Islamic da'wah activities carried out by congregations that have a sense of attachment to the mosque. ${ }^{10}$

Empowerment in the Oxford English Dictionary is a translation of the word empowerment which contains two meanings (1) to give power to (give power, transfer power or delegate authority to other parties). (2) to give ability to enable (effort to give ability). Anita Fauziah adds that empowerment comes from the word Daya which means strength or ability. ${ }^{11}$ Empowerment is an effort to increase the ability and potential of a community so that they can actualize their identity, desire and dignity maximally to survive and develop themselves independently. Rappaport defines empowerment as empowerment is viewed as a process: the mechanism by which people, organization and communities gain mastery over their lives. ${ }^{12}$

\footnotetext{
8 Ridin Sofwan, "Penguatan Manajemen Pemberdayaan Fungsi Masjid Al-Fattah di Kelurahan Krapyak Semarang", Dimas, Volume 13, Nomor 2 (2013), 124.

9 Nurseri Hasnah Wijaya Nasution, "Manajemen Masjid pada Masa Pandemi Covid 19", Yonetim: Jurnal Manajemen Dakwah, Volume 3, Nomor 1 (2020), 84-104.

${ }^{10}$ Ari Saputra dan Bayu Mitra Adhyatma Kusuma, "Revitalisasi Masjid dalam Dialektika Pelayanan Umat dan Kawasan Perekonomian Rakyat", Al-Idarah: Jurnal Manajemen dan Administrasi Islam, Volume 1, Nomor 1 (2017), 1-10.

${ }^{11}$ Anita Fauziah, Pemberdayaan Masyarakat Pedesaan (Jakarta: Bumi Aksara, 2009), 52.

12 J. Rappaport, "Empowerment Meets Narrative: Listening to Stories and Creating Settings", American Jornal of Community Psychology, Volume 23, Nomor 5 (1995), 192.
} 
The term empowerment has different meanings both in socio-culture and politics and cannot be translated easily into all languages. ${ }^{13}$ Added by Aprilia Theresia that however, the term empowerment as a translation word for the word empowerment is starting to be widely used in everyday language in Indonesia together with the term poverty alleviation. Several experts expressed their opinions regarding empowerment including. ${ }^{14}$

According to Hogan Christine defines empowerment as a process in which people achieve the capacity to control decisions affecting their lives. Empowerment enables people to define themselves and to construct their own identities. Empowerment can be the outcome of an intentional strategy which is either initiated externally by empowering agents or solicited by disempowered people. Empowerment allows a person to define and build their own identity. Empowerment can be the result of a deliberate strategy that is initiated externally by an empowerment agency or requested by disempowered people. ${ }^{15}$

Sumodiningrat stated that the concept of economic empowerment can be concluded, including 1) Community empowerment cannot be done only through the leaf, branch or stem or root approach because the problems faced do exist in each aspect. 2) Empowerment in the economic sector is not sufficient only by providing revolving capital, but also by strengthening community economic institutions, strengthening human resources, providing infrastructure, and strengthening the bargaining position. 3) Community empowerment in the economic field or strengthening the people's economy must be carried out elegantly without hindering and discriminating against strong economies, for this reason partnerships between micro, small, medium and large businesses are the way to be taken. 4) Community empowerment in the economic field is a process of strengthening the people's economy towards a strong, modern and efficient people's economy. 5) Community empowerment in the economic field cannot be done through an individual approach, but a group approach. ${ }^{16}$

According to Hatu Rauf that an empowerment program is only possible to realize empowerment indicators if it is implemented based on empowerment principles such as the principle of holism (an approach to a problem), sustainability, diversity, organic development, balanced development, and overcoming existing structures. ${ }^{17}$ These principles, if applied consequently, will become the empowerment program as an empowerment capable of empowering the community. ${ }^{18}$ To know the focus and objectives of empowerment operationally, it is necessary to know the various indicators of empowerment that someone says are empowered or not. So that when an empowerment program is given all efforts can be concentrated on any aspects of the target of change that need to be optimized. ${ }^{19}$ It can be

\footnotetext{
${ }^{13}$ Deepa Narayan, Empowerment and Poverty Reduction: A Source Book (Washington DC: The International Bank for Reconstruction and Development (2012), 158.

14 Aprilia Theresia. Empowerment: The Politics of Alternative Development (Cambridge Mass: Blackwell Publisher, 2015), 253.

15 Hogan Christine, Reinventing Government: How The Enterpreneurial Spirit is Transforming The Public Sector (Massachusetts: Addision Wesley Publishing Company Inc, 2015), 110.

${ }^{16}$ Gunawan Sumodiningrat, Membangun Perekonomian Rakyat (Yogyakarta: Pustaka Pelajar, 2015), 62.

${ }^{17}$ Hatu Rauf, Sosiologi Pembangunan (Gorontalo: Publikasi Interpena, 2010), 59.

${ }^{18}$ Syah Amelia Manggala Putri dan Eka Jati Rahayu Firmansyah, "Optimalisasi Laku Pandai Berbasis Masjid Guna Literasi dan Inklusi Keuangan Syariah Berkelanjutan”, Jurnal Ekonomi dan Bisnis Islam, Volume 3, Nomor 2 (2017), 106-120.

${ }^{19}$ Edi Suharto, Membangun Masyarakat Memberdayakan Rakyat, Kajian Strategis Pembangunan Kesejahteraan Sosial dan Pekerjaan Sosial (Bandung: Aditama, 2006), 72.
} 
concluded that empowerment is a program carried out to improve community welfare, as well as to increase the capacity so that people can improve their lives in a better direction and have responsibility for their own lives.

From an economic perspective, small and medium enterprises (UMKM) play a very vital role in economic growth and development. According to Yuli, UMKM are part of the economy that must be able to increase competitiveness by making innovations. ${ }^{20}$ The competitive advantage based on innovation and creativity must be prioritized because it has a longer durability and long term. This UMKM is regulated in Law No. 20 Article 1 of 2008 concerning Micro, Small and Medium Enterprises. The implementation of the mosque's social functions is running well, cannot be separated from the management. Management is a series that is based on planning, organizing, mobilizing and monitoring that aims to achieve organizational goals.

To carry out mosque management, there are three things that need to be done. ${ }^{21}$ First, it is necessary to implement mosque management functions which include a. Planning (Planning), b. Organizing (Organizing) c. Humanizing or Humanizing. d. Driving (Actuating) e. Supervision (Controlling) f. Integrating and g. Evaluation (Evaluating). Second, it is necessary to formulate general policies on both implementation and administrative techniques. Third, it is necessary to manage and develop various related aspects, including: a. Management and development of existing facilities, infrastructure and facilities owned by mosques. b. Management and development of mosque human resources. c. Management and financial development of mosques, $d$. Management and development of creative things through the educational process in the mosque environment to improve the quality of superior human resources.

According to the Central Statistics Agency (BPS), it provides a definition of UMKM based on the quantity of labor, namely micro businesses that have a workforce of 1 to 4 people, small businesses have a workforce of 5 to 19 people, while medium businesses have a workforce of 20 to 99 people. Urata in Malano Pratiwi, the role of UMKM can at least be seen from ${ }^{22}$ 1) Position as the main figure in economic activity in various sectors; 2) The largest employer; 3) Important figure in the development of local economic activities and community empowerment $\mathrm{d}$. New market creator and also a source of innovation.

In the perspective of its development, Micro, Small and Medium Enterprises (UMKM) are the business groups that have the largest number. In addition, this group has proven to be resistant to various shocks of economic crisis. So it is imperative to strengthen the Micro, Small and Medium Enterprises group that involves many groups. The following is the classification of Micro, Small and Medium Enterprises (UMKM) according to Bayun Wirani: ${ }^{23}$

\footnotetext{
${ }^{20}$ Yuli Rahmini Suci, "Perkembangan UMKM (Usaha Mikro Kecil dan Menengah) di Indonesia", Jurnal Ilmiah Cano Ekonomos, Volume 6, Nomor 1 (2017), 83.

${ }^{21}$ Wijaya Nurseri Hasnah Nasution, "Manajemen Masjid pada Masa Pandemi Covid 19", 84-104.

${ }^{22}$ Pratiwi Anggraeni, dkk, "Analsisi SWOT Pada UMKM Keripik Tempe Amel Malang dalam Rangka Meningkatkan Daya Saing Perusahaan”, Jurnal Administrasi Bisnis (JAB), Volume 43, Nomor 1 (2017), 61.

${ }^{23}$ Bayun Wirani, Model Usaha Mikro Kecil dan Menengah (Yogyakarta: Kajian Publishing Nyetak Buku, 2017), 85.
} 
1. Livelihood activities, is a Micro, Small and Medium Enterprise (UMKM) which is used as a job opportunity to earn a living, which is more commonly called the informal sector. For example, street vendors.

2. Micro enterprise, is a Micro, Small and Medium Enterprise (UMKM) which is craftsmen but not yet entrepreneurial.

3. Small dynamic enterprise, are Micro, Small and Medium Enterprises (UMKM) that have an entrepreneurial spirit and are able to accept subcontract and export jobs.

4. Fast moving enterprise, is a Micro, Small and Medium Enterprise (UMKM) which has an entrepreneurial spirit and will transform into a big business (UB).

In this case, UMKM will emphasize the role of mosques in economic empowerment and community welfare. UMKM as independent productive business units, carried out by individuals or business entities in the economic sector. In principle, the difference between micro, small and medium enterprises and large businesses is generally based on the initial asset value (excluding land and buildings), average annual turnover, or the number of permanent workers. However, the definition of UMKM based on this measuring tool is different depend on each country. ${ }^{24}$ Based on the literature review by the author, the author provides several explanations that have relevance to this research.

Referring to the results of research by Wahyu Panca Hidayat, it explains more about the patterns and ways of building human resources, especially for mosque managers, namely ta'mir. ${ }^{25}$ It is emphasized more on training and empowerment. The results of research by Ika Mituhuningrum contains of the development of the congregation recitation on Sunday morning at the al Furqon Mosque which is realized in various forms of formal and non-formal activities covering aspects that are engaged in education and mentoring. ${ }^{26}$ Through recitation forums and holding istighasah, pilgrimage for wali in an effort to increase the faith of the congregation, knowledge, and understanding through religious lectures, and improve the quality of worship.

The research on mosques that is directly related to the piety focus on the management of preaching is conducted by Fatkhuroji Hadi Wibowo, the researcher found the concept of fearlessness in carrying out supernatural activities towards the local community. In this study, it focuses more on applying the management function to the $t a^{\prime}{ }^{\prime} \overline{i r}$ of the Great Mosque of Tegal, in terms of program planning of ta'mir, motivating, organizing, actuating, until the last process evaluating. ${ }^{27}$

In the thesis of Khoirul Efendi, there is the description of the application of management functions such as planning, organizing the movement, and supervising the management of the Baitussalam Grand Mosque in preaching among the elite. His research focuses more on $d a^{\prime}$ wah strategies among officials, businessmen or it can be called the elite. ${ }^{28}$

\footnotetext{
24 Tulus Tambunan, UMKM di Indonesia (Bogor: Ghalia Indonesia, 2009), 11.

${ }^{25}$ Wahyu Panca Hidayat, "Strategi Pengembangan Jama'ah Masjid Jogokariyan" (Skripsi--Universitas Negeri Yogyakarta, 2013), 66.

${ }^{26}$ Ika Mituhuningrum, "Pengembangan SDM pada Jamaah Pengajian Ahad Pagi di Masjid al Furqon" (Skripsi-IAIN Sunan Kalijaga Yogyakarta, 2005), 73.

${ }^{27}$ Fatkhuroji Hadi Wibowo, "Manajemen Takmir Masjid Agung Tegal dalam Melaksanakan Kegiatan Dakwah" (Skripsi--Institut Agama Islam Negeri Semarang, 2009), 67.

28 Khoirul Efendi, "Manajemen Masjid Raya Baitussalam Komplek Billy Moon Jakarta Timur (Skripsi-Universitas Negeri Syarif Hidayatullah Jakarta, 2011), 42.
} 
While research conducted by Susapto focused more on the functions and roles of mosques in various fields. In his work, he also puts forward the quality of management or human resources who should be equipped with Islamic experience and knowledge in the hope of reaffirming the function and role of mosques in this modern era. ${ }^{29}$

Furthermore, the researcher also reads the thesis reference which examines the Micro, Small and Medium Enterprises (UMKM), conducted in 2013 by Dani Danur Tri U. In his work, he emphasizes the development of the creative economy-based business of the Semarang city community by prioritizing the characteristics of local products in the city of Semarang.

In the next literature review, the researcher reads the results of research that studies related to UMKM by Isnaini Nurrohmah. In her work, Isnaini applies the principle of financing capital lending with Musharaka financing through Beringhardjo Yogyakarta's BMT service in order to minimize the practice of interest applied to conventional financial institutions. ${ }^{30}$

From various references that researcher read, the researcher will bring up aspects that have not been discussed by previous authors. This proves that this research is still new and no one has conducted the same research. Hence, the researcher focuses more on the role of mosques in economic empowerment and community welfare through UMKM in the South Jakarta area. Because this research focuses more on economic empowerment and community welfare through training in entrepreneurship, leadership and community soft skills training.

\section{Research Methods}

The research objective is to map various basic concepts of community empowerment. In addition, to analyze the extent to which it is relevant to the role of the mosque in realizing the social and economic welfare of the community. It is underlain with the hope that more understanding will function the mosque as an effort to actualize and develop socio-economic values.

The stages carried out by assistants in the community empowerment process are as follows: Preparation stage, assessment, alternative planning, capacity building and networking programs, implementation and assistance, evaluation and termination. The types of data used in this study are primary data and secondary data.

This type of research is a descriptive analytic study. According to Sugiyono, analytical descriptive research is defined as research carried out by collecting data and information according to actual conditions, then the data is compiled, processed and analyzed to provide an overview of what roles are found, which are related to with the role of the mosque institution as the center of community socio-economic empowerment. ${ }^{31}$ This research method is qualitative research. This research approach is participatory action research, which is useful for being applied to community and group empowerment by directly interacting and

\footnotetext{
${ }^{29}$ Susapto, "Peran Masjid Jogokariyan dalam Pemberdayaan Masyarakat di Bidang Keagamaan, Pendidikan dan Ekonomi (Skripsi--Universitas Muhamadiyah Surakarta, 2010), 58.

${ }^{30}$ Isnaini Nurrohmah, "Analisis Perkembangan Usaha Mikro Kecil dan Menengah (UMKM) Sebelum dan Sesudah Menerima Pembiayaan Musyarakah Pada Koperasi Jasa Keuangan Syariah BMT (Studi Kasus BMT Bringhardjo Yogyakarta) (Skripsi--Universitas Negeri Yogyakarta, 2015), 44.

${ }^{31}$ Sugiyono, Metode Penelitian Kuantitatif, Kualitatif dan R\&B (Bandung: Alfabeta, 2012), 35.
} 
socializing, so that it will increase community capacity building and self-confidence. The real condition of the function of mosques today is still far from the example of the Prophet's time.

This real condition is exacerbated by the perception of some people who have not been able to accept the function of a mosque in many aspects of life, including the economic empowerment of the community and its congregation. Nevertheless, the economic empowerment of the mosque-based community has a bright prospect because it is supported by the condition of the community which continues to undergo a transformation towards modernity. It remains only how to prepare staff in the field of management who are expert, honest, and sincere.

The unit of analysis in this research is the role of the mosque institution. As an institution that has a very broad role, this research is focused on various programs, activities, and activities that have been carried out in empowering the community, especially in the socio-economic field.

The informant retrieval method used is Non Probability Sampling. The criteria for informants determined in this study are those who have insight and knowledge about the topic of the role of the mosque institution being studied. Informants are still or are currently involved in activities and programs at Pondok Indah Grand Mosque and Jami' Assakinah Mosque which are being studied, so that they are up to date on new problems and program developments, especially in the field of improving the community economy. ${ }^{32}$

The informants of this research are the administrators of Pondok Indah Grand Mosque and Jami' Assakinah Mosque, which consists of the Head of the Foundation, and various administrators who are responsible for the welfare improvement programs held at Pondok Indah Grand Mosque and Jami' Assakinah Mosque. And also the community who is given assistance and accesses business capital to BMT and PPM Masjid. Interviews were conducted openly and were not strictly structured. Observations are made directly at the start of the review.

\section{Potential of Pondok Indah Grand Mosque and Jami' Assakinah Mosque in Ummah Economic Empowerment}

Understanding the mosque universally also means to understand it as a social instrument of Islamic society that cannot be separated from the Islamic community it self. The existence of mosques in general is a manifestation of the aspirations of Muslims as places of worship that occupy a central function. Considering its strategic function, it is necessary to develop it as well as possible, both in terms of physical buildings and aspects of activities.

According to Ahmad Sutarmadi, a mosque does not only have a role and function as a means of worship for its congregation. The mosque has a broader mission covering the fields of religious education and knowledge, the field of enhancing social relations for members of the congregation, and improving the congregation's economy, according to the available local potential. the potential of Pondok Indah Mosque and Masjid Jami’ Assakinah, namely Human Resources (HR) owned by Pondok Indah Grand Mosque and Jami’ Assakinah Mosque are professional and qualified personnel who have mature knowledge and performance.

32 Bambang Supomo dan Nur Indriantoro, Metodologi Penelitian Bisnis (Yogyakara: Penerbit BFEE UGM, 2002), 37. 
On average, those who take charge of Pondok Indah Grand Mosque and Jami' Assakinah Mosque have an undergraduate degree. So that this is very influential in the management of the mosque and the policies that it issues. Besides that, professional staff can produce strategies and programs that are good for the welfare of the people.

\section{The Concept of Strategy for Empowerment and Improvement of the People of the Pondok Indah Grand Mosque (MRPI)}

As previously described regarding the instruments for increasing and empowering the economy or business activities owned by Pondok Indah Grand Mosque in South Jakarta, only a few parts will be described with consideration of the potential analysis of each instrument that can support optimization in the economic empowerment of the congregation. the surrounding community or the ummah. The results of the interview show that Pondok Indah Grand Mosque has units that handle mosque programs, for example in terms of improving and empowering the economy of the mosque community, it has formed and established a Baitul Mal Wat Tamwil (BMT). As the statement from the head of the Pondok Indah Grand Mosque office that for the economic empowerment of the community here, they have business units that handle everything like BMT, so everything is handled with BMT, and there is also LAZ. So the program is in the BMT unit, later it can be checked there.

The mosque can be the center of power for the people. In the past, during the time of the Prophet, the mosque could be maximally played as the center of Muslims for various activities. One of the economic activities owned by mosques that might be practiced and used as an example as a basis for community empowerment, especially in the economic sector and poverty alleviation is the formation of a mosque-based BMT.

A mosque with economic activities driven by BMT will be able to become the basis for economic empowerment of its congregation, as well as the Muslim community around it at large. For this reason, in maximizing the role and function of the mosque as the center of welfare for Muslims in carrying out activities, especially its economic activities, Pondok Indah Grand Mosque has implemented a strategy, namely by establishing Baitul Mal Wat Tamwil (BMT).

The practice in this BMT is for distribution, usually it is done by providing finance for people who need capital, either for trading or others. At BMT, this business provides financing services for various types of businesses and commerce. Businesses that are financed, among others, are in the form of trade, then the craft industry or what is called the home industry, as well as other businesses. On the other hand, BMT also serves consumptive financing with the principle of buying and selling as well as business cooperation with second parties through mushärakah and mudärabah schemes. Currently, there are 947 financing customers in BMT. The recipient of the financing is the community around the mosque and its scope is the South Jakarta area.

In addition to being an alternative institution for channeling capital, BMT also has a mission, namely realizing the movement to liberate members and society from the shackles of moneylenders, poverty traps, and the ribawi economy, the empowerment movement to increase capacity in the real and institutional economic movement towards a prosperous and 
advanced economic order and a building justice movement, and civil society structure based on sharia.

Judging from the growing development of BMT in Indonesia, it is undeniable that in practice, there are still many obstacles faced, such as the obstacles faced by BMT Masjid Raya Pondok Indah, and even experienced by other BMTs. One of the obstacles faced by $\mathrm{BMT}$ at this time is that financing customers do not have financial records or financial reports, as stated by the Head of BMT that there are several things that hinder and become obstacles, namely in terms of assistance and bookkeeping, especially financing customers. So here, the average financing customer has no books and it is a little difficult for BMT too.

It is different from loans in the banks, financing customers are required to report their finances/bookkeeping financial statements clearly. Therefore, this UKM group needs other or alternative financial institutions in order to facilitate them in accessing capital. However, BMT continues to provide assistance to financing customers, especially in compiling financial reports so as to minimize events that can hinder cooperation between BMT and financing customers.

\section{The Concept of Strategy for Increasing and Empowering the Welfare of the People of the Jami' Assakinah Mosque}

In contrast to the Pondok Indah Grand Mosque, the Jami' Assakinah Mosque has increased and empowered the economic welfare of the people by conducting a mosque micro loan program (PMM). In order to empower small (micro) businesses, so that these small businesses can continue to exist and even thrive in the midst of competition and the economic crisis that is hitting Indonesia. For this reason, Masjid Jami' Assakinah also made a strategy by creating a Mosque Micro Loan (PMM) program which aims to empower small entrepreneurs in developing their businesses and can prosper small traders. PMM helps small traders who do not have the capital to develop their business. In accordance to the narrative of the general chairman that then for implementation in the field, we have a strategy to increase empowerment of the community, namely the PMM program, namely mosque micro loans. We give loans to micro businesses so that their businesses can grow even more.

The Jami' Assakinah Mosque and its management take a strategic role to overcome this problem, the mosque which usually functions as a place of worship, in this case the Jami' Assakinah Mosque has the responsibility to educate and help the community around the mosque to reach its maximum potential so as to form useful community resilience for themselves and their environment.

\section{Implementation of Community Economic Improvement and Empowerment Programs Through Mosque Micro Loans (PPM)}

For small entrepreneurs, capital is the main factor in developing a business, with revolving capital. The Jami' Assakinah Mosque is conducting economic empowerment through the Mosque Micro Loan (PMM) program. It is hoped that the mosque micro-loan can help small traders from difficulties and make their businesses grow, so that their lives become more prosperous. PMM program funds are channeled in the form of loans to small businesses around the Jami' Assakinah mosque. Small businesses that are given loans include food and 
beverage, vegetable and fruit traders, staple goods traders, clothing traders and other traders. As of 2019, mosque micro loans have been distributed to 118 borrowers as well as 64 borrowers who have repaid their loans. Most loans are given to food and beverage traders, the second loan is for basic needs.

Table 1.1. Number of Mosque Micro Loans (PMM) by Business Sector

\begin{tabular}{|c|l|c|}
\hline No & Business that is Given a Loan & Amount Borrowed \\
\hline 1 & Food and Drink & 44 \\
\hline 2 & Basic Material Needs & 37 \\
\hline 3 & Vegetables and Fruits & 8 \\
\hline 4 & Clothes & 14 \\
\hline 5 & Etc & 15 \\
\hline
\end{tabular}

Source: Mosque Micro Loan Profile (PMM) Year 2019

In every strategy implemented by an organization to achieve the maximum program, of course, there is certain obstacle to deal with. Even so in the Mosque Micro Loan Program, there are still obstacles to be faced. It should be noted that this PPM is given to small entrepreneurs who are already running their business but are experiencing obstacles with capital. This loan is given without any compensation or profit sharing, so this program is deliberately made by the mosque management which is for social purposes or in other words that the contract used the tabarru' contract. The mosque only facilitates traders to easily access capital in order to advance their business. Therefore, in its implementation, there are still obstacles faced by PMM administrators, including the money used in this PMM program coming from mosques whose sources come from mosque donors. So that this existing capital will continue to be rotated to provide loans to other parties in need. However, there are some people who find it difficult to return the capital on time. Thus, the difficulty is even greater for the PMM management to roll back the capital to other parties. It was previously known that the PMM capital came from mosque money which came from mosque donors. So that entrepreneurs who are empowered are limited to about 118 borrowers. To address this, of course, another solution is to maximize the role of PMM in enhancing and empowering the economy of the people.

According to the researchers' opinion, the mosque should establish a sharia microfinance institution, so that this institution can maximize the economic empowerment of the people. If we look at the potential that the Jami' Assakinah Mosque has, it has great potential in establishing Islamic microfinance institutions.

At Pondok Indah Grand Mosque, the use of the building is utilized by leasing it to the public. The income from renting the building is used for the maintenance of the mosque and for the salaries of employees. So that there are efforts among fellow administrators to overcome daily needs and help each other by maximizing the function of the mosque to build economic strength that takes advantage of all the potential of the mosque, be it the potential of the congregation, the potential location of the mosque, the economic potential of the community around the mosque, and the potentials of the mosque. other. If all these potentials can be managed properly, the problems of unemployment and poverty, which are the main enemies of Muslims today, will be minimized. 


\section{Economic Empowerment of the Dhuafa Through Business Capital and Production Facilities}

The economic level of the assisted community, which consists of the poor, has an increase in income. Even though it is not too drastic, it is enough to help people overcome their economic difficulties. These following are some of the assisted members who received business capital assistance:

1. Sujiman, a housekeeper who sold cassava chip in order to get higher earnings. She distributed her products in several stalls. Her financial capital was Rp. 750.000,-. Then, through BMT, she got a greatly tremendous development. She always reports her business development to BMT.

2. H. Mamad, a food seller, received a working capital of Rp. 2,500,000,-. His business was growing and his daily income increased compared to before he got capital. In addition, $\mathrm{H}$. Mamad and his children actively participate in coaching.

3. Jumiati is a new fostered member in the public economy. In 2018, he owes a lot to money lenders. As an effort to empower the economy, he received a venture capital of Rp. 500,000 ,- as well as a cart for selling fried $u d u k$ rice and traditional cakes. Until now her business has grown and Jumiati has been able to pay off her debt to loan sharks.

\section{Empowering the Community Economy Through the Members of the Mosque Cooperative}

At the Jami' Assakinah Mosque and Pondok Indah Grand Mosque as large mosques that have many congregations, employees and staffs, attention is also shown by paying attention to the welfare of the congregation, mosque apparatus or employees who so far have often been neglected such as prayer imams, muadzin, Koran teachers, marbot who are thought about, covered and endeavored to make welfare at the mosque. The mosque cooperative involves a member that has savings, and also for employees, they find it easy to borrow. There is also KSSPS, namely mudāarabah savings, education savings, eid al-qurban, umrah, etc.

\section{Business Training for Fostering Members}

The economy of the Pondok Indah Grand Mosque and the Jami' Assakinah Mosque has many congregations/members and mustahiq who have small and medium enterprises such as meatball businesses, various rice dishes, handicrafts, as well as various kinds of cakes. These business actors are brought together to become members of cooperatives and given various trainings to develop their businesses. As for the purpose of this program is for the welfare of the people.

\section{The Concept of the Strategy for the Empowerment of the People of the Pondok Indah Grand Mosque}

As previously described regarding economic empowerment instruments or business activities owned by the Pondok Indah Grand Mosque in South Jakarta, only a few parts will be described with consideration of the potential analysis of each instrument that can support optimization in the economic empowerment of the congregation, the surrounding community. or the ummah. 
As with the interviews that have been conducted, the Pondok Indah Grand Mosque has several units that handle mosque programs, for example in terms of economic empowerment, the mosque community has formed and established a Baitul Mal Wat Tamwil (BMT). As the statement from the head of the Pondok Indah Grand Mosque office that for the economic empowerment of the community here, they have business units that handle everything like BMT, so everything is handled with BMT, and there is also LAZ. So the program is in the BMT unit, later it can be checked there.

The mosque can be the center of power for the people. In the past, during the time of the Prophet, the mosque could be maximally played as the center of Muslims for various activities. One of the economic activities owned by mosques that might be practiced and used as an example as a basis for community empowerment, especially in the economic sector and poverty alleviation is the formation of a mosque-based BMT. A mosque with economic activities driven by BMT that it builds will be able to become the basis for economic empowerment of its congregation, as well as the Muslim community around it at large. For this reason, in maximizing the role and function of the mosque as a center for Muslims in carrying out activities, especially its economic activities, Pondok Indah Grand Mosque has implemented a strategy, namely by establishing BMT.

\section{Concept of Strategy for Empowerment of the People of the Jami' Assakinah Mosque}

In contrast to the Pondok Indah Grand Mosque, the Jami' Assakinah Mosque has empowered the economy of the people by conducting a mosque micro loan program (PMM). In order to empower small (micro) entrepreneurs, so that these small entrepreneurs can continue to exist and even thrive in the midst of competition and the economic crisis hitting Indonesia. For this reason, the Jami' Assakinah Mosque also made a strategy by creating a Mosque Micro Loan (PMM) program which aims to empower small entrepreneurs (micro) in developing their businesses and can prosper small traders (micro). PMM helps small traders who do not have the capital to develop their business.

In accordance with the narrative of the general chairman of the Jami' Assakinah Mosque, Mr. H. Agus Setiadi that for implementation in the field they have a strategy to empower the people, namely the PMM program, namely mosque micro loans. They give loans to micro entrepreneurs so that their businesses can develop even more.

The Jami' Assakinah Mosque Institute and its management take a strategic role to overcome this problem. Due to the existence of the mosque which usually functions as a place of worship, in this case, the Jami' Assakinah Mosque has the responsibility to educate and help the community around the Jami mosque to reach its maximum potential as to form the resistance of the people beneficial for themselves and the environment.

\section{Conclusion}

Based on the research results that have been described, the following conclusions can be drawn:

1. The Jami' Assakinah Mosque and the Pondok Indah Grand Mosque revive various functions of the mosque, such as worship, social education, health, and economy.

2. The existence of mosque administrators as facilitators as well as educators and assistants 
brings great benefits to the community. Many people have been helped, such as the poor, the unemployed, and the people who have been helped both from their social and economic programs.

\section{References}

Anggraeni, Pratiwi, dkk. "Analsisi SWOT Pada UMKM Keripik Tempe Amel Malang dalam Rangka Meningkatkan Daya Saing Perusahaan", Jurnal Administrasi Bisnis (JAB), Volume 43, Nomor 1 (2017).

Chaidir, Achmad. Strategi Peningkatan Peran Lembaga Kemasyarakatan dalam Penanggulangan Kemiskinan di Kota Pekanbaru. Riau: Universitas Riau, 2009.

Chrismardani, Yustina. "Komunikasi Pemasaran Terpadu: Implementasi untuk UMKM", Jurnal Neo-bis, Volume 8, Nomor 2, (2014).

Christine, Hogan. Reinventing Government: How The Enterpreneurial Spirit is Transforming The Public Sector. Massachusetts: Addision Wesley Publishing Company Inc, 2015.

Dalmeri. "Revitalisasi Fungsi Masjid Sebagai Pusat Ekonomi dan Dakwah", Jurnal Walisongo, Volume 22, Nomor 2 (2014).

Efendi, Khoirul. "Manajemen Masjid Raya Baitussalam Komplek Billy Moon Jakarta Timur. Skripsi--Universitas Negeri Syarif Hidayatullah Jakarta, 2011.

Fauziah, Anita. Pemberdayaan Masyarakat Pedesaan. Jakarta: Bumi Aksara, 2009.

Hidayat, Wahyu Panca. "Strategi Pengembangan Jama'ah Masjid Jogokariyan”. Skripsi-Universitas Negeri Yogyakarta, 2013.

Mannuhung, Suparman, dkk. "Manajemen Pengelolaan Masjid dan Remaja Masjid di Kota Palopo", Jurnal Pengabdian Masyarakat, Volume 1, Nomor 1 (2018).

Mardikanto. Konsep Pemberdayaan Masyarakat. Surakarta: Tiga Serangkai, 2010.

Mituhuningrum, Ika. "Pengembangan SDM pada Jamaah Pengajian Ahad Pagi di Masjid al Furqon”. Skripsi--IAIN Sunan Kalijaga Yogyakarta, 2005.

Narayan, Deepa. Empowerment and Poverty Reduction: A Source Book. Washington DC: The International Bank for Reconstruction and Development (2012).

Nasution, Nurseri Hasnah Wijaya. "Manajemen Masjid pada Masa Pandemi Covid 19", Yonetim: Jurnal Manajemen Dakwah, Volume 3, Nomor 1 (2020).

Nurrohmah, Isnaini. "Analisis Perkembangan Usaha Mikro Kecil dan Menengah (UMKM) Sebelum dan Sesudah Menerima Pembiayaan Musyarakah Pada Koperasi Jasa Keuangan Syariah BMT (Studi Kasus BMT Bringhardjo Yogyakarta). Skripsi-Universitas Negeri Yogyakarta, 2015.

Putri, Syah Amelia Manggala dan Eka Jati Rahayu Firmansyah, "Optimalisasi Laku Pandai Berbasis Masjid Guna Literasi dan Inklusi Keuangan Syariah Berkelanjutan”, Jurnal Ekonomi dan Bisnis Islam, Volume 3, Nomor 2 (2017).

Rappaport, J. "Empowerment Meets Narrative: Listening to Stories and Creating Settings", American Jornal of Community Psychology, Volume 23, Nomor 5 (1995).

Rauf, Hatu. Sosiologi Pembangunan. Gorontalo: Publikasi Interpena, 2010.

Saputra, Ari dan Bayu Mitra Adhyatma Kusuma. "Revitalisasi Masjid dalam Dialektika Pelayanan Umat dan Kawasan Perekonomian Rakyat", Al-Idarah: Jurnal Manajemen dan Administrasi Islam, Volume 1, Nomor 1 (2017). 
Sofwan, Ridin. "Penguatan Manajemen Pemberdayaan Fungsi Masjid Al-Fattah di Kelurahan Krapyak Semarang”, Dimas, Volume 13, Nomor 2 (2013).

Suci, Yuli Rahmini. "Perkembangan UMKM (Usaha Mikro Kecil dan Menengah) di Indonesia", Jurnal Ilmiah Cano Ekonomos, Volume 6, Nomor 1 (2017).

Sugiyono. Metode Penelitian Kuantitatif, Kualitatif dan R\&B. Bandung: Alfabeta, 2012.

Suharto, Edi. Membangun Masyarakat Memberdayakan Rakyat, Kajian Strategis Pembangunan Kesejahteraan Sosial dan Pekerjaan Sosial. Bandung: Aditama, 2006.

Suherman, E. Manejemen Masjid Kiat Sukses Meningkatkan Kualitas SDM Melalui Optimalisasi Kegiatan Umat Berbasis Pendidikan Berkualitas Unggul. Bandung: Alfabeta, 2012.

Sumodiningrat, Gunawan. Membangun Perekonomian Rakyat. Yogyakarta: Pustaka Pelajar, 2015.

Supomo, Bambang dan Nur Indriantoro. Metodologi Penelitian Bisnis. Yogyakara: Penerbit BFEE UGM, 2002.

Susanto, Dedi. "Penguatan Manajemen Masjid Darussalam di Wilayah RW 1V Kelurahan Banjardowo Kecamatan Genuk Kota Semarang”. Skripsi--Universitas Semarang, 2014.

Susapto. "Peran Masjid Jogokariyan dalam Pemberdayaan Masyarakat di Bidang Keagamaan, Pendidikan dan Ekonomi. Skripsi--Universitas Muhamadiyah Surakarta, 2010.

Tambunan, Tulus. UMKM di Indonesia. Bogor: Ghalia Indonesia, 2009.

Theresia, Aprilia. Empowerment: The Politics of Alternative Development. Cambridge Mass: Blackwell Publisher, 2015.

Wibowo, Fatkhuroji Hadi. "Manajemen Takmir Masjid Agung Tegal dalam Melaksanakan Kegiatan Dakwah”. Skripsi--Institut Agama Islam Negeri Semarang, 2009.

Wirani, Bayun. Model Usaha Mikro Kecil dan Menengah. Yogyakarta: Kajian Publishing Nyetak Buku, 2017. 